\title{
Hypnotic effect of ecdysterone isolated from Pfaffia glomerata (Spreng.) Pedersen
}

\author{
Raquel Fenner, Aline R. Zimmer, Gilda Neves, Michele Kliemann, Grace Gosmann, \\ Stela M. K. Rates*
}

Programa de Pós-Graduação em Ciências Farmacêuticas, Faculdade de Farmácia, Universidade Federal do Rio Grande do Sul, Av. Ipiranga, 2752, 90610-000 Porto Alegre-RS, Brazil

\begin{abstract}
RESUMO: "Efeito hipinótico de ecdisterona isolada de Pfaffia glomerata (Spreng.) Pedersen". Neste trabalho foi avaliado, em roedores, o efeito depressor das frações clorofórmio $\left(\mathrm{CHCl}_{3}\right)$, acetato de etila (EtOAc) e n-butanol, obtidas das partes subterrâneas de Pfaffia glomerata, empregando-se o teste de tempo de sono barbitúrico como referência. Somente a fração lipofílica $\left(\mathrm{CHCl}_{3}\right.$ :EtOAc, 1:1, m/m) (i.p. $500 \mathrm{mg} / \mathrm{kg}$; v.o. $1000 \mathrm{mg} / \mathrm{kg}$ ) potenciou o tempo de sono induzido por pentobarbital. A ecdisterona foi isolada e identificada como constituinte majoritário $(1,4 \% \mathrm{~m} / \mathrm{m})$ desta fração, através de cromatografia líquida de alta eficiência e métodos espectroscópicos, respectivamente. Este composto potenciou o tempo de sono barbitúrico (100 mg/kg, i.p.; $400 \mathrm{mg} / \mathrm{kg}$, v.o), sem causar hipotermia. Nestas mesmas doses, a ecdisterona não alterou a performance dos animais no rota-rod, esquiva inibitória e labirinto em cruz-elevado, além de não alterar o padrão de convulsões induzidas por pentilenotetrazol. Este perfil indica que esta substância, nestas doses, não apresenta perfil ansiolítico ou neurotóxico. Estes resultados indicam que a ecdisterona é o componente responsável pela ação hipnótica apresentada pela fração lipofílica obtida das partes subterrâneas de $P$. glomerata.
\end{abstract}

Unitermos: Pfaffia glomerata, Amaranthaceae, ecdisterona, efeito depressor, sistema nervoso central, tempo de sono induzido por pentobarbital.

\begin{abstract}
In this study the depressant effect of fractions from $P$. glomerata was initially evaluated using the mice barbiturate sleeping time test as reference. The fractions tested were the $\mathrm{CHCl}_{3}$, the EtOAc, the $\mathrm{n}-\mathrm{BuOH}$ and the aqueous fraction obtained from P. glomerata subterraneous parts. Only the pretreatment with the lipophilic fraction $\left(\mathrm{CHCl}_{3}\right.$ : EtOAc, 1:1, w/w) increased the barbiturate sleeping time (i.p $500 \mathrm{mg} / \mathrm{kg}$; v.o. $1000 \mathrm{mg} / \mathrm{kg}$ ). Ecdysterone, the main substance isolated from this lipophilic fraction, was identified by spectroscopic methods and its content in the ethanol extract was determined as $1.4 \%(\mathrm{w} / \mathrm{w})$ by HPLC. In order to investigate the hypothesis of ecdysterone displaying a depressant effect on nervous central system, an evaluation toward the hypnotic-sedative and anxiolytic effects of this drug was carried out. Ecdysterone $100 \mathrm{mg} / \mathrm{kg}$, i.p, increased the barbiturate sleeping time without provoking hypothermia; when administered by oral route its minimal effective dose was $400 \mathrm{mg} / \mathrm{kg}$. On the other hand, ecdysterone $(100 \mathrm{mg} / \mathrm{kg}$, i.p; $400 \mathrm{mg} / \mathrm{kg}$, p.o) did not impair motor coordination and was ineffective on pentylenetetrazoleinduced convulsion, elevated plus-maze and step-down inhibitory avoidance tests, indicating that at these doses the drug does not present an anxiolytic profile and does not cause manifest neurotoxic effects as well. In conclusion, the lipophilic fraction from $P$. glomerata presents a hypnotic effect being ecdysterone one of the compounds responsible for this CNS activity.
\end{abstract}

Keywords: Pfaffia glomerata, Amaranthaceae, ecdysterone, central depressant effect, pentobarbital-induced sleeping time.

\section{INTRODUCTION}

The genus Pfaffia (Amaranthaceae) comprises about ninety species distributed through Central and South America, twenty-seven of them being described in Brazil (Taniguchi et al., 1997). Pfaffia paniculata, popularly known as "Brazilian ginseng" (Oliveira, 1986), is the most employed and commercialized species in Brazil as a surrogate for Panax spp. (ginseng
- Araliaceae). Furthermore, the substitution of $P$. paniculata by Pfaffia glomerata is also common due to falsification or botanical misidentification (DeParis et al., 2000). Recently some quality parameters to differentiate between $P$. paniculata and P. glomerata roots have been described considering their botanical and chemical characteristics (Gosmann et al., 2003). Ecdysterone (Figure 1) was only found in P.glomerata, as already described (Shiobara et al., 1993), so it seems that 
this compound could be a good marker for differentiation of both species. Allantoin, ecdysteroids, pfaffic acid and their glycosides (nortriterpene saponins), stigmasterol and sitosterol have been isolated from subterraneous parts of Pfaffia species (Nakai et al., 1984, Nishimoto et al., 1984, Takemoto et al., 1982).

Pharmacological studies with $P$. glomerata roots evidenced a gastroprotective effect probably mediated by histaminergic pathway and an enhanced production of nitric oxide in the stomach (Freitas et al., $2003,2004)$. An ethanol extract of this species did not show antiviral, antiproliferative, antifungal or MAO inhibitory activities in vitro (Gosmann et al., 2003). A crude hydroalcoholic extract of $P$. glomerata roots presented analgesic and anti-inflammatory activities (Neto et al., 2005).

Regarding to the central nervous system action, the administration of a crude ethanol extract of $P$. glomerata by intraperitoneal route produces a depressor effect in the barbiturate sleeping time test and an amnesic effect in adult rodents (De-Paris et al., 2000; Vigo et al., 2003). On the other hand, Marques et al. (2004) reported a barbiturate sleeping time decrease and an improvement in learning and memory in old mice chronically treated.

The aim of this work was to evaluate the central nervous activity of $P$. glomerata fractions and its main isolated compound toward the hypnotic-sedative, anxiolytic and memory effects.

\section{MATERIAL AND METHODS}

\section{Plant material}

Pfaffia glomerata (Spreng.) Pedersen subterraneous parts were obtained from the cultivated area of the Centro Pluridisciplinar de Pesquisas Químicas, Biológicas e Agrícolas (CPQBA/UNICAMP, Campinas, SP, Brazil) and a voucher specimen is kept in the herbarium-UNICAMP (CPQBA 0238). Roots and rhizomes (subterraneous parts) from $P$. glomerata were reduced to small pieces, dried in a circulating air stove $\left(40{ }^{\circ} \mathrm{C}\right)$ and then triturated to powder.

\section{Ethanol extract and fractions from Pfaffia glomerata}

The ethanol extract from $P$. glomerata subterraneous parts was prepared as already described (De-Paris et al., 2000). The fractions from P. glomerata subterraneous parts $(1000 \mathrm{~g})$ were obtained using soxhlet during $12 \mathrm{~h}$ and, successively, solvents of increasing polarity to obtain the $\mathrm{CHCl}_{3}(2 \mathrm{~g}, 0.2 \% \mathrm{w} / \mathrm{w})$, the EtOAc ( $7 \mathrm{~g}, 0.7 \% \mathrm{w} / \mathrm{w})$ and the $\mathrm{n}-\mathrm{BuOH}(16 \mathrm{~g}, 1.6 \%$ $\mathrm{w} / \mathrm{w})$ fractions, which were evaporated, separately, to dryness. The remainder vegetal residue was submitted to decoction under stirring during $1 \mathrm{~h}$, and then the resulting aqueous fraction (600 g, 60\% w/w) was lyophilized. $\mathrm{CHCl}_{3}$ and EtOAc fractions were pooled due to similar TLC profile. The fractions used in pharmacological experiments were named $\mathrm{CAE}\left(\mathrm{CHCl}_{3}\right.$ and EtOAc, $1: 1$, w/w), BUT (n-BuOH) and AQU (aqueous).

\section{Isolation of ecdysterone}

The main constituent in the organic fraction was isolated from P. glomerata roots $(1500 \mathrm{~g})$ through soxhlet using EtOAc. EtOAc fraction was concentrated until half volume and cooled resulting in a precipitate with a major compound which was purified using $\mathrm{CHCl}_{3}$ until obtaining a white powder $(5 \mathrm{~g}, 0.3 \%$ yield, $\mathrm{w} / \mathrm{w}$, relating to the dried plant). The isolated product was identified as ecdysterone (ECD) (Figure 1) by spectroscopic and HPLC analysis. FAB-MS spectrum was performed on a MS50 spectrometer. ${ }^{1} \mathrm{H}$ and ${ }^{13} \mathrm{C}$ NMR spectra were recorded on Bruker AMX 500 spectrometer.

Ecdysterone: White powder. UV $\lambda_{\max } 242$ (EtOH); FABMS $m / z=503.2[\mathrm{M}+\mathrm{Na}]^{+}, 481.3[\mathrm{M}$ $+\mathrm{H}]^{+} ;{ }^{1} \mathrm{H}$ and ${ }^{13} \mathrm{C}$ NMR (500 MHz, $\left.\mathrm{C}_{5} \mathrm{D}_{5} \mathrm{~N}\right)$ the same as Nishimoto et al. (1987); HPLC: the same as under quantification. Chromatographic peak was identified at $242 \mathrm{~nm}$ by comparison of the retention time $(3.40 \mathrm{~min})$ and co-chromatography to ecdysterone Sigma ${ }^{\circledR}$.

\section{HPLC quantification of ecdysterone}

The quantification of ecdysterone (ECD) present in the ethanol extract of $P$. glomerata was carried out in a liquid chromatograph Shimadzu LC$10 \mathrm{~A}$ as already described using an HPLC methodology previously validated (Zimmer et al., 2005).

\section{Animals}

Adult male Wistar rats (weight 200-300 g) and adult male CF1 mice (weight 25-30 g) from Fundação Estadual de Produção e Pesquisa em Saúde (FEPPS, Porto Alegre, RS, Brazil) breeding colony were used. The animals were housed in plastic cages, five by cage, under a $12 \mathrm{~h}$ light/dark cycle (lights on at 7:00 a.m.) at constant temperature of $23 \pm 1{ }^{\circ} \mathrm{C}$ with free access to standard certified rodent diet and tap water. All experiments were performed between 10:00 and 16:00 $\mathrm{h}$.

All experiments were approved by the Research Ethical Committee of Universidade Federal do Rio Grande do Sul (\# 2003236).

\section{Drugs and treatments}

Pentobarbital sodium salt (PTB, Abbot ${ }^{\circledR}$, São Paulo, SP, Brazil), pentylenetetrazole (PTZ, Sigma ${ }^{\circledR}$, St. Louis, MO) and diazepam (DZP, Valium ${ }^{\circledR}$, Roche $^{\circledR}$ ) were used. 
The aqueous fraction, pentobarbital, pentylenetetrazole were dissolved in physiological saline $(\mathrm{NaCl} 0.9 \%)$. Other fractions, ecdysterone and diazepam were suspended in saline with the addition of polysorbate 80 at $1 \% \mathrm{v} / \mathrm{v}$. All administrations were made in a volume of $1 \mathrm{ml} / 100 \mathrm{~g}$ body weight (mice), except for the inhibitory avoidance task, where the rats were treated with a $2 \mathrm{ml} / \mathrm{kg}$ volume. When oral route was used, all the animals were fasted for $6 \mathrm{~h}$ before testing.

\section{Barbiturate sleeping time test}

Different groups of mice were treated with different $P$. glomerata fractions or ecdysterone, saline (SAL), saline + polysorbate $801 \%$ (TWE) and diazepam by intraperitoneal and oral routes. Thirty minutes after intraperitoneal injection and $60 \mathrm{~min}$ after gavage, all groups received pentobarbital $(40 \mathrm{mg} / \mathrm{kg}$, i.p.) and the time elapsed between the loss and voluntary recovery of the righting reflex was recorded as sleeping time. A ceiling of $240 \mathrm{~min}$ was imposed in this measure, i.e., animals whose sleeping time was over $240 \mathrm{~min}$ were counted as $240 \mathrm{~min}$. Sleep latency was also recorded. The room temperature was kept at $23 \pm 1{ }^{\circ} \mathrm{C}$.

\section{Rota-rod motor coordination test}

The rota-rod consisted of a cylinder of $3 \mathrm{~cm}$ of diameter at a height of $21 \mathrm{~cm}$ from the base. One day before testing, mice were placed on the cylinder for training during $5 \mathrm{~min}$. On the test day, the animals were placed on the bar and selected based on their ability to remain at least $90 \mathrm{~s}$ continuously on the rotating bar at the speed of $5 \mathrm{rpm}$. Immediately after, the selected mice were treated with the test substances and replaced on the cylinder $60 \mathrm{~min}$ later. In both sessions, the parameters registered were number of falls and the maximum time of permanence on the bar through $5 \mathrm{~min}$. The following groups were tested: TWE (saline + polysorbate $801 \%$, $\mathrm{n}=9)$, ecdysterone $400 \mathrm{mg} / \mathrm{kg}(\mathrm{n}=9)$, ecdysterone $800 \mathrm{mg} / \mathrm{kg}(\mathrm{n}=8)$ and diazepam $(5 \mathrm{mg} / \mathrm{kg}, \mathrm{n}=10)$. All groups were treated orally.

\section{Effect on pentylenetetrazole-induced convulsions}

Groups of mice were treated with ecdysterone $100 \mathrm{mg} / \mathrm{kg}(\mathrm{n}=13)$, TWE (saline + polysorbate $801 \%, \mathrm{n}$ $=14)$ and diazepam $(1 \mathrm{mg} / \mathrm{kg}, \mathrm{n}=10)$ by intraperitoneal route. pentylenetetrazole $(80 \mathrm{mg} / \mathrm{kg}$ i.p. $)$ was given 30 $\mathrm{min}$ after the intraperitoneal administration. The latency and duration of the first convulsion and number of death were taken into account.

\section{Elevated plus-maze}

The elevated plus-maze consists of two open arms $(30 \times 10 \mathrm{~cm})$ and two enclosed arms $(30 \times 10 \times$<smiles>C[C@@H]([C@@H](O)CCC(C)(C)O)[C@@H]1CC[C@]2(O)C3=CC(=O)[C@H]4CC(O)[C@@H](O)CC4(C)[C@H]3CC[C@]12C</smiles>

Figure 1. Ecdysterone.

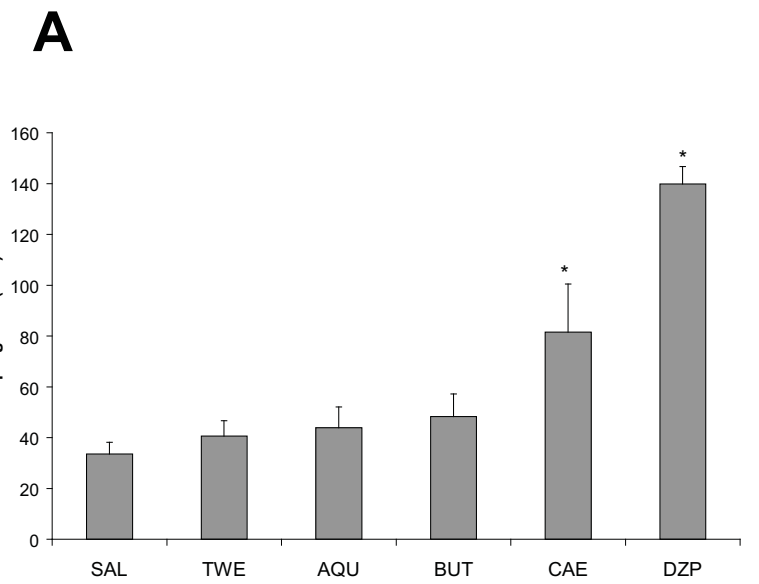

B

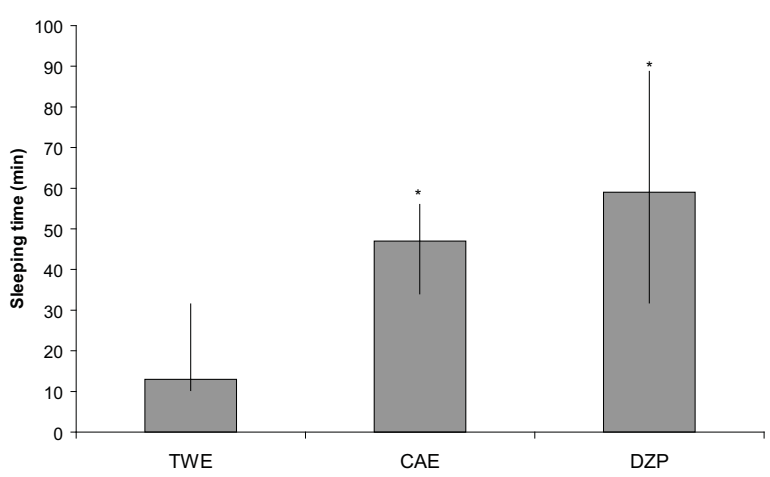

Figure 2. Effects of pretreatment with $P$. glomerata fractions (AQU, BUT and CAE) and diazepam (DZP) on sleeping time induced by pentobarbital $(40 \mathrm{mg} / \mathrm{kg}$ i.p.) in mice.

A) Treatments: SAL - saline i.p. $(\mathrm{n}=18)$; TWE - saline + polysorbate $801 \%$ i.p. $(\mathrm{n}=.13)$; AQU $500 \mathrm{mg} / \mathrm{kg}$ i.p. $(\mathrm{n}=9)$; BUT $500 \mathrm{mg} / \mathrm{kg}$ i.p. $(\mathrm{n}=9)$; CAE $500 \mathrm{mg} / \mathrm{kg}$ i.p. $(\mathrm{n}=10)$; DZP $1 \mathrm{mg} / \mathrm{kg}$ i.p. $(\mathrm{n}=16)$. The data are reported as mean \pm standard error (*different from SAL and TWE groups. ANOVA; $\left.\mathrm{F}_{5,74}=25.71 ; \mathrm{p}<0.001\right)$.

B) Treatments: TWE - saline + polysorbate $801 \%$ p.o. $(\mathrm{n}=$ 11); CAE $1000 \mathrm{mg} / \mathrm{kg}$ p.o. $(\mathrm{n}=10)$; DZP $2 \mathrm{mg} / \mathrm{kg}$ p.o. $(\mathrm{n}=$ 13). The data are reported as median and interquartile intervals (*different from TWE group. Kruskal-Wallis; $\mathrm{H}=12.65 ; \mathrm{p}=$ $0.002)$.

$15 \mathrm{~cm}$ ), arranged in such a way that the two arms of each type were opposite one another. The maze is $50 \mathrm{~cm}$ 


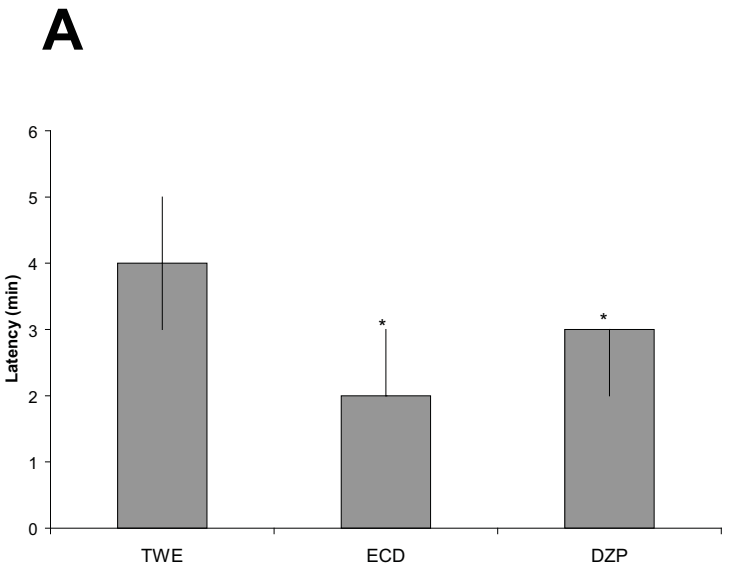

B

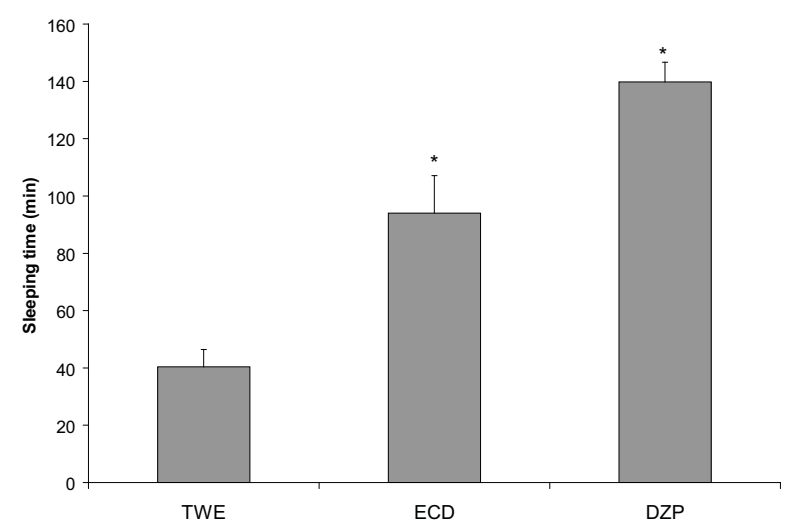

Figure 3. Effects of pretreatment with ECD (100 mg/kg i.p.; $\mathrm{n}$ $=12$ ) and diazepam (DZP $1 \mathrm{mg} / \mathrm{kg}$ i.p.; $\mathrm{n}=16$ ) on latency (A) and sleeping time (B) induced by pentobarbital ( $40 \mathrm{mg} / \mathrm{kg}$ i.p.) in mice. Control group: TWE - saline + polysorbate 80 1\% i.p. $(\mathrm{n}=13)$.

A) The data are reported as median and interquartile intervals (*different from TWE group. Kruskal-Wallis; $\mathrm{H}=17.16$; $\mathrm{p}<$ $0.001)$.

B) The data are reported as mean \pm standard error $(*$ different from TWE group. ANOVA; $\left.\mathrm{F}_{2,40}=33.63 ; \mathrm{p}<0.001\right)$.

high and the tests were conducted under shadow. During a 5 min test period, the following measurements were recorded by two observers: the number of entries and the time spent in open and enclosed arms, the exploratory behavior (total number of arm entries) and the number of rearing and risk assessments of mice. The groups evaluated were: TWE (saline + polysorbate $801 \%, \mathrm{n}=$ $8)$, ecdysterone $400 \mathrm{mg} / \mathrm{kg}(\mathrm{n}=8)$ and diazepam $(2 \mathrm{mg} /$ $\mathrm{kg}, \mathrm{n}=13$ ). All groups were treated orally $60 \mathrm{~min}$ before the test.

\section{Step-down inhibitory avoidance task}

A $50 \times 30 \times 25 \mathrm{~cm}$ plastic box with a frontal glass wall and whose floor was made of parallel $10 \mathrm{~mm}$ caliber bronze bars was used. The left end of the grid

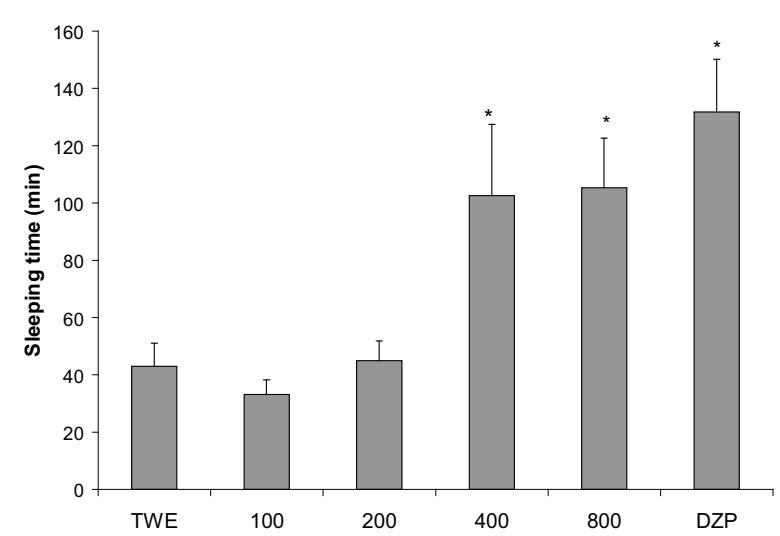

Figure 4. Effects of pretreatment with ECD (100, 200, $400 \mathrm{e}$ $800 \mathrm{mg} / \mathrm{kg}$ p.o.; $\mathrm{n}=12$ ) and diazepam (DZP $2 \mathrm{mg} / \mathrm{kg}$ p.o.; $\mathrm{n}=$ 13) on sleeping time induced by pentobarbital ( $40 \mathrm{mg} / \mathrm{kg}$ i.p.) in mice. Control group: TWE - saline + polysorbate $801 \%$ p.o. $(n=13)$. The data are reported as mean \pm standard error (*different from TWE group. ANOVA; $\left.\mathrm{F}_{5,69}=8.29 ; \mathrm{p}<0.001\right)$.

was occupied by a $10 \mathrm{~cm}$ wide, $4.5 \mathrm{~cm}$ high platform. The rats were gently placed on the platform facing the rear wall and their latency to step-down, placing their four paws on the grid was measured. After steppingdown the animals received a $0.4 \mathrm{~mA}, 2 \mathrm{~s}$ scrambled foot shock and were immediately withdrawn from the cage. Twenty-four hours later, the procedure was repeated but the foot shock was not given. Then, the step-down latency was taken a measure of memory retention. A ceiling of $180 \mathrm{~s}$ was imposed in this measure, i.e., animals whose test latency was over than $180 \mathrm{~s}$ were counted as $180 \mathrm{~s}$. The following groups were tested: TWE (saline + polysorbate $801 \%, \mathrm{n}=8$ ); ecdysterone $400 \mathrm{mg} / \mathrm{kg}(\mathrm{n}=9)$ and diazepam $(2 \mathrm{mg} / \mathrm{kg}, \mathrm{n}=7)$. All groups were treated orally $60 \mathrm{~min}$ before the first session (training session).

\section{Influence upon core temperature}

The treatments were administered immediately

Table 1. Performance of mice treated with ecdysterone 400 mg:kg and 800 mg:kg p.o. (ECD), diazepam 5 mg:kg p.o. (BZD) and saline + polysorbate $801 \%$ p.o (TWE) in the rotarod test.

\begin{tabular}{lcccc}
\hline & \multicolumn{2}{c}{ Number of falls } & \multicolumn{2}{c}{$\begin{array}{c}\text { Maximum time of } \\
\text { permanence (s) }\end{array}$} \\
\hline & T0 & T60 & T0 & T60 \\
TWE & $2.2 \pm 0.9$ & $1.2 \pm 0.6$ & $213 \pm 25$ & $225 \pm 22$ \\
BZD & $2.6 \pm 0.9$ & $9.0 \pm 2.0^{*}$ & $189 \pm 27$ & $106 \pm 28^{*}$ \\
ECD 400 & $0.7 \pm 0.4$ & $3.1 \pm 1.3$ & $263 \pm 12$ & $197 \pm 31$ \\
ECD 800 & $1.7 \pm 0.5$ & $1.6 \pm 0.7$ & $221 \pm 22$ & $207 \pm 22$ \\
\hline
\end{tabular}

T0: immediately before treating; T60: sixty minutes after treating. The data are reported as mean \pm standard error (*different from T0. Two way repeated measures ANOVA; $\mathrm{F}_{1,71}$ $=5.09 ; \mathrm{p}<0.05)$. 
Table 2. Behavior of mice treated with ecdysterone $400 \mathrm{mg}: \mathrm{kg}$ p.o. (ECD) and diazepam $2 \mathrm{mg}: \mathrm{kg}$ p.o. (BZD) and saline + polysorbate $801 \%$ p.o (TWE) in the elevated plus-maze test.

\begin{tabular}{ccccc}
\hline & $\begin{array}{c}\text { Entries (\%) } \\
\text { Open } \\
\text { arms }\end{array}$ & $\begin{array}{c}\text { Time spent (\%) } \\
\text { Open } \\
\text { arms }\end{array}$ & $\begin{array}{c}\text { Entries (\%) } \\
\text { Enclosed } \\
\text { arms }\end{array}$ & $\begin{array}{c}\text { Time spent (\%) } \\
\text { Enclosed } \\
\text { arms }\end{array}$ \\
\hline ECD & 15 & 07 & 85 & 93 \\
BZD & 47 & 55 & 53 & 45 \\
TWE & 13 & 13 & 87 & 87 \\
\hline
\end{tabular}

Table 3. Effects of ecdysterone $100 \mathrm{mg}: \mathrm{kg}$ i.p. (ECD) and diazepam $1 \mathrm{mg}: \mathrm{kg}$ i.p (BZD) and saline + polysorbate $801 \%$ i.p. (TWE) on PTZ ( $80 \mathrm{mg} / \mathrm{kg}$ )-induced convulsions in mice.

\begin{tabular}{lccc}
\hline \multicolumn{1}{c}{ Group } & $\begin{array}{c}\text { Latency } \\
(\mathrm{s})\end{array}$ & $\begin{array}{c}\text { Duration } \\
(\mathrm{s})\end{array}$ & $\begin{array}{c}\text { Deaths } \\
(30 \mathrm{~min})\end{array}$ \\
\hline TWE & $67.0(57.8-78.3)$ & $1.0(1.0-1.0)$ & 2 \\
ECD & $76.5(58.0-97.0)$ & $1.0(1.0-1.0)$ & 1 \\
BZD & - & - & 0 \\
\hline
\end{tabular}

The data are expressed as median and interquartiles ranges.

Table 4. Performance of rats treated with ecdysterone 400 mg:kg. (ECD), diazepam 2 mg:kg p.o. (BZD) and saline + polysorbate $801 \%$ p.o (TWE) in the step-down inhibitory avoidance task.

\begin{tabular}{lll}
\hline & Training (s) & Test (s) \\
\hline TWE & $7.7 \pm 1.7$ & $91.1 \pm 31.4^{*}$ \\
ECD & $8.7 \pm 2.4$ & $64.6 \pm 27.3^{*}$ \\
BZD & $4.1 \pm 1.1$ & $10.6 \pm 5.3$ \\
\hline
\end{tabular}

* The data are reported as mean \pm standard error $(*$ different from Training session. Two way repeated measures ANOVA; $\left.\mathrm{F}_{1,71}=5.09 ; \mathrm{p}<0.05\right)$.

after the determination of basal temperature as described by Neves et al. (2003). Subsequent measurements were done 15, 30, 60 and $90 \mathrm{~min}$ after the drug injection. The following treatments were used: saline (i.p. $\mathrm{n}=8), P$. glomerata ethanol extract $(500 \mathrm{mg} / \mathrm{kg}$, i.p., $\mathrm{n}=10)$, ecdysterone $100 \mathrm{mg} / \mathrm{kg}$, i.p. $(\mathrm{n}=8)$ and apomorphine $(1$ $\mathrm{mg} / \mathrm{kg}$, i.p., $\mathrm{n}=9$ ).

\section{Statistical analysis}

All statistical analyses were done using the Sigma Stat software (version 2.03; Jandel Scientific Corporation $\left.{ }^{\circledR}\right)$. The specific test was selected accordingly with the experimental design of each animal model. They are specified in the corresponding results.

\section{RESULTS AND DISCUSSION}

Previous results by our group indicated that the ethanol extract of $P$. glomerata presented maximal effect at $500 \mathrm{mg} / \mathrm{kg}$ i.p. in the barbiturate sleeping time test (De-Paris et al., 2000). Based on these results, the bioguided fractionation strategy was proceeded using the same animal model as reference test.

In order to characterize the $P$. glomerata extract, HPLC quantification of ecdysterone in the EtOH extract was determined as $1.4 \%(\mathrm{w} / \mathrm{w})$ in relation to the dried extract.

The fractions CAE, BUT and AQU were administered by intraperitoneal route at $500 \mathrm{mg} / \mathrm{kg}$ and tested on the barbiturate sleeping test. Only the pretreatment with CAE increased the sleeping time (Figure 2A) without any effect on the latency to sleep (data not shown). This lipophilic fraction kept its effect on the sleeping time when orally administered (1000 $\mathrm{mg} / \mathrm{kg}$, Figure 2B). Following, ecdysterone, the main substance isolated from CAE, was tested. Ecdysterone $100 \mathrm{mg} / \mathrm{kg}$ i.p. caused a decrease in the latency and an increase on the sleeping time (Figures $3 \mathrm{~A}$ and $3 \mathrm{~B}$ ). The same treatment did not alter the core temperature of mice (data not shown). These results indicate a depressant effect of ecdysterone. Thus, the effect of ecdysterone per os $(100,200,400$ and $800 \mathrm{mg} / \mathrm{kg})$ on the pentobarbitalsleeping time was evaluated. Ecdysterone $400 \mathrm{mg} / \mathrm{kg}$ and $800 \mathrm{mg} / \mathrm{kg}$, p.o., increased the sleeping time (Figure 4) but it did not change the latency to sleep in any tested dose (data not shown).

These results suggest that ecdysterone is responsible for the depressant effect of the ethanol extract on the barbiturate sleeping time test. The differences between the activities of the ethanol extract and ecdysterone when administered orally could be a consequence of the low systemic levels obtained for ecdysterone after the ethanol extract administration due to the drug poor bioavailability by this route in addition to its low content in this extract $(1.4 \%)$.

Ecdysterone is a steroid molecule which is extensively studied as an insect's hormone. More recently some biological activities in mammals have been reported on normal and tumor cellular metabolism (Wu \& Wang., 2003, Konovalova et al., 2002). Ecdysterone also improved the learning and memory in the Morris Water Maze and increased the expression of c-fos into the hippocampus of rats (Yang et al., 2004). Thus, it is plausible that ecdysterone represents a type of neuractive steroid (NAS).

The term neuroactive steroid (NAS) refers to steroids which, independent of their origin, are capable of modifying neural activities. NAS are involved in several psychiatric disorders, including depression syndromes, stress responses, anxiety disorders and memory processes and pre-menstrual syndrome (Amin et al., 2006). The neurosteroid dehydroepiandrosterone cause an increase in the sleep time induced by ethanol or pentobarbital (Melchior \& Ritzman, 1992). Some NAS have been shown to exert hypnotic, sedative and anticonvulsive effects, mainly through $\mathrm{GABA}_{\mathrm{A}}$ receptor modulation (for review see Dubrovsky, 2005).

Thus the hypothesis of ecdysterone presenting effects on GABA system was investigated by testing the drug on animal models of anxiety, convulsions and memory which are recognized as useful tools to detect benzodiazepine-like or GABAergic drugs (Izquierdo \& 
Medina, 1997, Rodgers \& Dalvi, 1997, Cooper et al., 1996): elevated plus-maze, PTZ-induced convulsions test and step-down inhibitory avoidance.

In addition, since substances with hypnoticsedative action have a great potential to interfere with motor activity parameters the effect of ecdysterone (400 and $800 \mathrm{mg} / \mathrm{kg}$ v.o.) was evaluated in the rotarod test. It did not alter any parameter evaluated (Table 1), demonstrating that it does not impair the motor coordination of the animals and does not manifest neurotoxic effects as well.

None of the parameters evaluated in the plusmaze test were modified by the pre-administration of ecdysterone ( $400 \mathrm{mg} / \mathrm{kg}$ v.o.) (Table 2). Ecdysterone (100 $\mathrm{mg} / \mathrm{kg}$ i.p.) still did not protect the mice from the PTZinduced convulsions (Table 3). Additionally, ecdysterone ( $400 \mathrm{mg} / \mathrm{kg}$ v.o.) did not incite any change in the stepdown inhibitory avoidance rat's performance (Table 4). This test is a classical model to take measurements of memory with a strong aversive component. Thus, this result point out that probably ecdysterone is not the substance responsible for the amnesic effect previously reported to the ethanol extract (De-Paris et al., 2000).

With the results obtained so far it can be assumed that the liphofilic fraction from $P$. glomerata when acutely administered to adult rodents present a hypnotic effect that could be attributed to ecdysterone. This effect seems not to be mediated by the GABAergic system since ecdysterone was ineffective in animals models considered predictive of benzodiazepine-like or GABAergic effects.

\section{ACKNOWLEDGMENTS}

The authors thank CNPq (Plano Sul de Pesquisa e Pós-Graduação), CAPES, FAPERGS and PROPESQ/ UFRGS (Brazil) for fellowships and financial support. We are also grateful to Ílio Montanari (Centro Pluridisciplinar de Pesquisas Químicas, Biológicas e Agrícolas, CPQBA/UNICAMP, Campinas, SP, Brazil) for providing plant material.

\section{REFERENCES}

Amin Z, Mason GF, Cavus I, Krystal JH, Rothman DL, Epperson $\mathrm{CN}$ 2006. The interaction of neuroactive steroids and GABA in the development of neuropsychiatric disorders in women. Pharmacol Biochem Behav 84: 635-643.

Cooper JR, Blomm FE, Roth RH 1996. The Biochemical Basis of Neuropharmacology, vol. 48. New York: Oxford University Press, p. 145.

De-Paris F, Neves G, Salgueiro JB, Quevedo J, Izquierdo I, Rates SMK 2000. Psychopharmacological screening of Pfaffia glomerata Spreng. (Amaranthaceae) in rodents. J Ethnopharmacol 73: 261-269.

Dubrovsky BO 2005. Steroids, neuroactive steroids and neurosteroids in psychopathology. Prog
Neuropsychopharmacol Biol Psych 29: 169-192.

Freitas CS, Baggio CH, Silva-Santos JE, Rieck L, Santos CAM, Corrêa Júnior C, Ming LC, Cortez DAG, Marques MCA 2004. Involvement of nitric oxide in the gastroprotective effects of an aqueous extract of Pfaffia glomerata (Spreng.) Pedersen, Amaranthaceae, in rats. Life Sci 74: 1167-1179.

Freitas CS, Paula MFR, Rieck L, Marques MCA 2003. Actions of crude hydroalcoholic extract of Pfaffia sp on gastrointestinal tract. Braz Arch Biol Technol 46: 355-360.

Gosmann G, Gattuso S, Gattuso M, Fenner R, Pacheco EF, Ferraz A, Savi LA, Barardi CRM, Simões MO, Sortino M, Zacchino S, Gnerre C, Testa B, Rates SMK 2003. Botanical (morphological, micrographic), chemical and pharmacological characteristics of Pfaffia species (Amaranthaceae) native to South Brazil. Braz J Pharm Sci 39: 141-147.

Izquierdo I, Medina, H 1997. Memory formation: the sequence of biochemical events in the hippocampus and its connection to activity in other brain structures. Neurobiol Learn Mem 68: 285-360.

Konovalova NP, Mitrokhin IUI, Volkova LM, Sidorenko LI, Todorov IN 2002. Ecdysterone modulates antitumor activity of cytostatics and biosynthesis of macromolecules in tumor-bearing animals. Izv Akad Nauk Ser Biol 6: 250-258.

Marques LC, Galvao SM, EspinolaE, Dias RF, Mattei R, Oliveira MG, Carlini ELA 2004. Psychopharmacological assessment of Pfaffia glomerata roots (extract BNT-08) in rodents. Phytother Res 18: 566-572.

Melchior CL, Ritzmann RF 1992. Dehydroepiandrosterone enhances the hypnotic and hypothermic effects of ethanol and pentobarbital. Pharmacol Biochem Behav 43: 223-227.

Nakai S, Takagi N, Miichi H, Hayashi S, Nishimoto N, Takemoto T, Kizu H 1984. Pfaffosides, nortriterpenoid saponins, from Pfaffia paniculata. Phytochemistry 23: 1703-1705.

Neto AG, Costa JM, Belati CC, Vinholis AH, Possebom LS, Da Silva Filho AA, Cunha WR, Carvalho JCT, Bastos JK, Silva MLA 2005. Analgesic and anti-inflammatory activity of a crude root extract of Pfaffia glomerata (Spreng.) Pedersen. J Ethnopharmacol 96: 87-91.

Neves G, Fenner R, Heckler AP, Viana AF, Tasso L, Menegatti R, Fraga CAM, Barreiro EJ, Dalla-Costa T, Rates SMK 2003. Dopaminergic profile of new heterocyclic $\mathrm{N}$-phenylpiperazine derivatives. Braz J Med Biol Res 36: 625-629.

Nishimoto N, Nakai S, Takagi N, Hayashi S, Takemoto T, Odashima S, Wada Y 1984. Pfaffosides and nortriterpenoid saponins from Pfaffia paniculata. Phytochemistry 23: 139-142.

Nishimoto N, Shiobara Y, Fujino M, Inoue S-S, Takemoto T, Oliveira F, Akisue G, Akisue M K, Hashimoto G, Tanaka O, Kasai R, Matsuura H 1987. Ecdysteroids from Pfaffia iresinoides and reassignment of some ${ }^{13} \mathrm{C}$ NMR chemical shifts. Phytochemistry 26: 2505-2507.

Oliveira F 1986. Pfaffia paniculata (Martius) Kuntze - o ginseng brasileiro. Rev Bras Farmacogn 1: 86-92.

Rodgers RJ, Dalvi A 1997. Anxiety, defense and the elevated plus-maze. Neurosci Biobehav Rev 21: 801-810. 
Shiobara Y, Inoue S-S, Kato K, Nishiguchi Y, Oishi Y, Nishimoto N, Oliveira F, Akisue G, Akisue MK, Hashimoto G 1993. A nortriterpenoid, triterpenoids and ecdysteroids from Pfaffia glomerata. Phytochemistry 32: 1527-1530.

Takemoto T, Nishimoto N, Nakai S, Takagi N, Hayashi S, Odashima S, Wada Y 1982. Pfaffic acid, a novel nortriterpene from Pfaffia paniculata Kuntze. Tetrahedron Lett 24: 1057-1060.

Taniguchi SF, Bersani-Amado CA, Sudo L, Assef SMC, Oga S 1997. Effect of Pfaffia iresinoides on the experimental inflammatory process in rats. Phytother Res 11: 568-571.

Vigo CLS, Narita E, Nakamura CV, Marques LC 2003. Avaliação dos efeitos das raízes de Pfaffia glomerata (Spreng.) Pedersen sobre o tempo de sono e crescimento bacteriano. Rev Bras Farmacogn 13 (Supl.): 14-17.

Wu X, Wang WJ 2003. Protective effect of ecdysterone against sodium arsenite-induced endothelial cell apoptosis. Di Yi Jun Yi Da Xue Xue Bao 23: 1219-1221.

Yang SF, Yang ZQ, Zhou QX, Wu Q, Huang XN, Shi JS 2004. Effect of ecdysterone on the expression of c-fos in the brain of rats induced by microinjection betaAP25-35 into the hippocampus.Yao Xue Хue Bao 39: 241-244.

Zimmer AR, Bruxel F, Bassani VL, Gosmann G 2005. HPLC method for the determination of ecdysterone in extractive solution from Pfaffia glomerata. J Pharm Biomed Anal 40: 450-453. 